\title{
Determinants of the role of gender on adoption of row planting of tef [Eragrostis tef (Zucc.) Trotter] in central Ethiopia
}

\author{
Almaz Giziew ${ }^{1, *}$ and Begashaw Mebrate ${ }^{2}$
}

'Bahir Dar University, College of Agriculture and Environmental Sciences, Department of Rural Development and Agricultural Extension, Ethiopia. Email: almazgzw@gmail.com; Cell phone number: +251913356360

${ }^{2}$ Adventist Development and Relief Agency (ADRA), Agriculture Development Officer, Awra Woreda, Afar Region, Ethiopia. Email: bigide2006@gmail.com, Cell phone number: 09233660397

\begin{abstract}
Teff is a major indigenous cereal crop in Ethiopia, produced for household consumption and income generation. The determinant factors of adoption of teff row planting by female farmers vis-à-vis their male counterparts are not understood. Therefore, a survey was conducted to identify factors that determine adoption of teff row planting technology in a gender perspective in Moretna Jiru district, North Shoa, Ethiopia. A random sample of 131 male and 31 female headed households were randomly taken from four kebeles (lowest administrative unit) of the district. Primary data was collected from sample respondents and secondary data from various other sources. Descriptive statistics and Tobit regression were used in data analysis. Tobit regression was used to identify determinant factors of adoption. The findings of the marginal effect revealed that $81 \%$ of the female headed households (FHH) had favorable attitude towards the technology, a year increase in schooling increased the intensity of use of the technology by $39 \%$ and one ha increase in land holding size increased it by $30 \%$. With regard to male headed households $(\mathrm{MHH})$, positive attitude towards the technology increased the intensity of use of the technology by $39 \%$, getting extension service by $38 \%$ and increase in education by $24 \%$. In conclusion, extension agents should work hard with female headed farmers and ensure the implementation of teff row planting technology by strengthening FTCs via improved resources.
\end{abstract}

Keywords: Adoption, Gender, Intensity of Adoption, Marginal effect, Tobit DOI: https://dx.doi.org/10.4314/ejst.v12i1.2

* Corresponding author: almazgzw@gmail.com 


\section{INTRODUCTION}

Teff (Eragrostis teff) is cereal grain native to Ethiopia. It is one of the most common and favorite food of majority Ethiopians. Adopting teff technologies could significantly enhance poverty reduction and economic growth. Women in Ethiopia account for fifty percent of the country's population. The Ethiopian government took women farmers as strategy to reduce poverty and hunger. Hence, women's empowerment is crucial for poverty reduction and for accomplishing Millennium Development Goals. Unequal participation of women in adoption of agricultural technologies hampers economic growth of a country. On the other hand, equal participation of men and women in adoption of crop production contributes greatly for solving Ethiopia's economic growth problem (MoFED, 2010; ATA, 2016).

Teff planting methods such as broadcasting, row planting and transplanting are some of the factors that affect teff production. Most farmers practice traditional method of planting by broadcasting of teff seeds at a seed rate of 25 to $30 \mathrm{~kg}$ ha-1 (Berhe and Zena, 2008). Broadcasting wastes seeds unnecessarily (increases cost of production), creates excess seedling density and intensifies inter-plant competition (for nutrients, water, sunlight and carbon dioxide). Because of high plant density, plant lodging is likely to happen in a broadcast teff, eventually reducing the yield (Berhe, 2009).

Compared to broadcasting method, row planting gives better yield. To minimize lodging, low seed rate, row planting, late sowing and application of plant growth regulators were used (Abebe and Workayehu, 2015). Row planting of teff, rather than broadcasting method, improves production and productivity (ATA, 2013a). The Ethiopian government promoted these new technologies on a large scale. Since 2013, teff row planning method was adopted by almost 2.5 million teff growers through the national extension system and farm radio partnerships (ATA, 2013a; Vandercasteelen et al., 2016). As a result, average grain yield increased from 12.6 to about 21 quintals/ha or by $70 \%$ (ATA, 2013b). Broadcasting method gave an average grain yield of $17.1 \mathrm{q} / \mathrm{ha}$. Yield of row planting method reached about $24 \mathrm{q} / \mathrm{ha}$ and the net revenue was $20 \%$ larger than the traditional broadcasting method (Behailu, 2014). 
Row planting method has now become the latest farming technology aggressively promoted for adoption by smallholder farmers in Ethiopia (Geremew et al., 2016). According to Moretna Jiru District Office of Agriculture (2014) report, MoA and ATA introduced teff row planting technology in 2012 to the district and it was first applied on selected Farmer Training Center (FTCs) (row planting and transplanting of seedlings). After that, the district agriculture office continued to scale up the adoption of the technology to the entire kebeles. Despite such interventions, adoption of row planting technology in Ethiopia and specifically in the study district is still low. However, continued investments by the Government have helped farmers increase their crop production and productivity by adopting yield-enhancing inputs so that farmers can benefit from economies of scale (ATA, 2016).

In Moretna Jiru district, teff is also grown by female-headed households. Therefore, it was found advisable to study the determinant factors of adoption of female farmers vis-à-vis their male counterparts in the area where gender dis-aggregated information is missing. Farmers in the study area have started adopting teff row planting technology. However, adoption of this technology alone is not enough to achieve the desired level of yield unless farmers properly apply the different components of the technology, i.e., the package, based on recommendations. Row planting technology and its impact on household income has been investigated before (Fufa et al., 2011; Vandercasteelen et al., 2013; Behailu, 2014; Yonas, 2014; Debelo, 2015; Geremew et al., 2016; Begashaw, 2018). However, these studies did not show factors influencing adoption and its intensity in a gender perspective. No empirical information exists about the determinants of adoption and its use intensity in a gender dimension. The objective of the survey was, therefore, to identify gender related factors that determine adoption of teff row planting technology in Moretna Jiru district of Ethiopia. 


\section{MATERIALS AND METHODS}

A survey was conducted in Moretna Jiru district, North Shoa Zone, Amhara National Regional Sate, Ethiopia, in 2016/17 cropping year. Moretna Jiru district encamps 20 kebeles (18 rural and 2 small town) with a total population of 105,980 people and an area of $661.2 \mathrm{~km}^{2}$ (District Agriculture Office, 2016).

The district is known cereals producing area, especially wheat and teff. In 2016 alone, a little over 6 thousand ha of land was allotted for teff, a third of which was row-planted and the rest broadcast (District Agriculture Office, 2016).

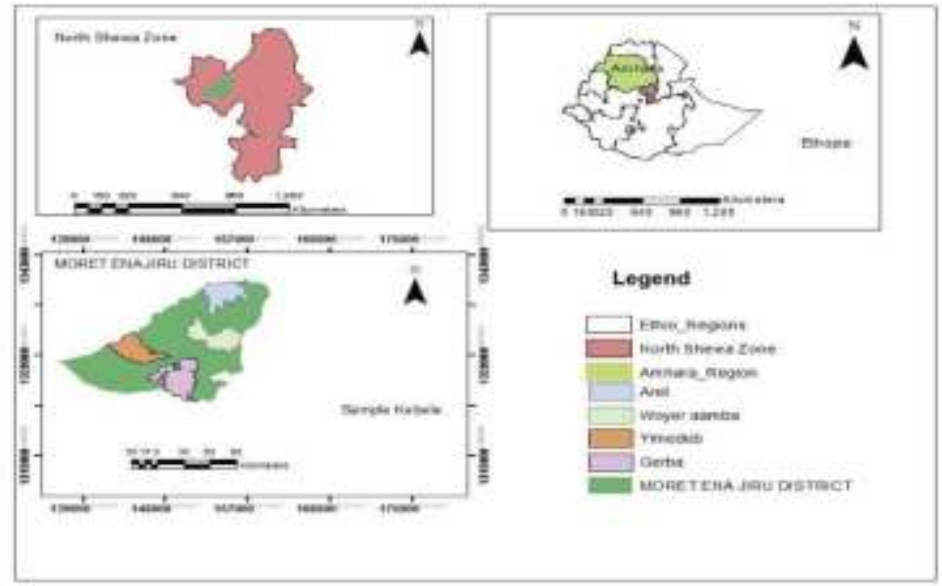

Figure 1. Location map of the study area (Moretena Jiru district)

\section{Sampling procedure}

A multi-stage sampling technique was employed. Moretna Jiru woreda was purposively selected as potential area for teff production. Teff row planting technology has been introduced there before and practiced for years now. The district is the best known for cereal production in the North Shoa Zone. 
In the second stage, kebeles were stratified as highland and lowland agro-ecological zones. In the third stage, out of a total of 18 kebeles, 4 kebeles were randomly selected, i.e., two from the highland and two from the lowland.

At the fourth stage, teff grower household heads of each selected rural kebele were identified in collaboration with kebele leaders, key informants and development agents of the respective kebeles. At the fifth stage, teff growers in the selected kebeles were stratified as maleheaded and female- headed households. Finally, the number of respondents for male-headed households (MHH) was determined by using probability proportional to size sampling procedure. With reference to the sample selection of female-headed households (FHH), the same procedure was followed as male-headed households (MHH). Finally, respondents from each selected kebele were identified using probability proportional to population size random sampling technique to get a total sample size of 164 households (131 $\mathrm{MHH}$ and $33 \mathrm{FHH}$ ). Table 1 shows the population size of each kebele administration with respect to teff grower households in each kebele and the representative samples taken.

Table 1. Number of household heads sampled at each kebele

\begin{tabular}{lrrrrrrr}
\hline \multirow{2}{*}{ Kebeles } & \multicolumn{2}{c}{$\begin{array}{c}\text { Number of household } \\
\text { heads }\end{array}$} & \multicolumn{3}{c}{$\begin{array}{c}\text { Number of teff } \\
\text { growers }\end{array}$} & \multicolumn{2}{c}{$\begin{array}{c}\text { Respondents } \\
\text { selected (No.) }\end{array}$} \\
\cline { 2 - 8 } & MHH & FHH & Total & MHH & FHH & MHH & FHH \\
\hline Woyramba & 577 & 144 & 721 & 349 & 85 & 28 & 8 \\
Aret & 377 & 94 & 471 & 347 & 53 & 26 & 5 \\
Yimedeb & 751 & 188 & 939 & 399 & 106 & 31 & 10 \\
Gerba & 982 & 246 & 1228 & 596 & 110 & 46 & 10 \\
Total & 2687 & 672 & 3359 & 1691 & 354 & 131 & 33 \\
\hline Notes: "FHH" & stands for female-headed households, "MHH" for male-headed \\
households & \multicolumn{1}{c}{ "MH }
\end{tabular}

\section{Method of data collection and analysis}

Primary and secondary data were collected. Primary data was collected through face-to-face interview using structured and pretested interview questionnaire that was filled up by recruited and trained enumerators under close supervision of the researcher. Secondary data were obtained from various sources such as reports of 
district office of agriculture, CSA reports, district administrative office, previous research findings, the internet and other published and unpublished materials which are found to be relevant to the study.

The data were analyzed using SPSS version 21 and STATA 11 software. Quantitative data analysis was employed by using simple descriptive statistics such as percentage, mean, frequency and standard deviations. By classifying the respondents into different adoption groups, F-test, t-test, and Chi-square tests were employed to determine differences or relationships. In addition, Tobit statistical model was used to determine the relative influence of various explanatory variables on the dependent variable.

\section{Analytical techniques}

Adoption is a decision to make full use of an innovation (Rogers, 1983). Before analyzing the determinants of adoption, it is important to assess the level of adoption for each farm household. Accordingly, farmers who were not growing teff in row planting method were considered as non-adopters, while farmers who were growing teff in row with some of the recommended agronomic practices were considered as adopters. Among improved agronomic practices (planting methods, spacing, seed rate, weeding rate and fertilizer rate) were currently practiced by farmers who planted teff in rows.

Adoption index scores were calculated by adding up the adoption quotient of each practice and dividing it by number of adopted practices of each respondent. The adoption quotient of each practices was calculated by taking the ratio of actual rate applied to the recommended rate. In this study, adoption index was used to measure the extent of adoption at the time of the survey for multiple practices (package), which shows to what extent the respondent farmer has adopted the most set of packages. In order to identify the intensity of adoption of new technology, adoption index of individual farmers was developed with the help of the following formula (Singh, 1992).

The index for each respondent farmer was estimated as: 
$\mathrm{AI}_{\mathrm{i}}=\sum_{i=1}^{n} \frac{\left[\frac{A H i}{A T i}+\frac{S R A i}{S R R}+\frac{F A i}{F R}+\frac{I R S A i}{I R S}+\frac{W A i}{W R}\right]}{N P}$

Where: $\mathrm{i}=1,2,3 \ldots \ldots \ldots \mathrm{n}$, and $\mathrm{n}=$ total number of respondent farmers $\mathrm{AIi}=$ Adoption index of ith farmer, $\mathrm{i}=1,2,3 \ldots \ldots \mathrm{n}$ and $\mathrm{n}=$ Total number of respondent farmer

$A H i=$ Area under teff row planting technology of the ith farmer.

$A T i=$ Total area allocated for teff production (row planting + broadcasting) of the ith farmer.

$S R A i=$ Seed rate applied per unit area in the production of teff with row planting method of ith farmer.

$S R R=$ Seed rate recommended for application per unit of area.

$F A i=$ Fertilizer rate applied per unit area in the cultivation of teff row planting by ith farmer.

$F R=$ Amount of fertilizer recommended for application per unit of area in the cultivation of teff in row planting techniques.

$I R S A i=$ Average intra row spacing applied by ith farmer with row planting method.

$I R S=$ Intra row spacing recommended for teff row planting method of sowing in $(\mathrm{cm})$.

$W A i=$ Actual weed rate (number/year) applied on teff with row planting method by ith farmer,

$W R i=$ Recommended weed rate (number/year) for teff with row planting method of sowing.

$N P=$ Number of practices.

Thus, the adoption index is continuous dependent variable calculated using the above formula; its values vary between zero and one. Zero indicates no adoption whatsoever, and 1 indicates full adoption. After calculating the adoption index, respondent farmers were classified into three categories, low, medium, and high adopter.

Teff row planting technology involves the use of a production package including row planting, seed rate, fertilizer rate, spacings, planting without trampling the field, etc. However, none of them 
trampled their fields and therefore trampling was not considered in calculating adoption index. Teff production and productivity depends on the extent to which a household has practiced the recommended improved agronomic practices. The level of adoption of row planting by farmers may vary depending on demographic and socioeconomic variables, although institutional and environmental factors also influence level of adoption. The actual adoption index score ranges from 0 to 1 . The sample households' index scores were categorized into four adopter groups' namely non adopter, low, medium and high adopter. Adoption index score of zero point implies non-adoption of the row planting technology and greater than zero $(>0$ and $\leq 1)$ implies adopters with any of the three adoption categories namely low adopters, medium adopters and high adopters.

\section{Operational definition of variables}

Table 2 presents the operational definition of dependent and independent variables with its expected sign and measurement types.

\section{RESULTS AND DISCUSSION}

\section{Status of adoption and intensity of adoption}

In this study, teff row planting technology encompasses use of different practices of a production package including row planting, seed rate, intra-row spacing and fertilizer application. Teff row planting production package includes four practices that are recommended by research system. Out of these, only row planting, seed rate, intra-row spacing and fertilizer application were used for calculating adoption index.

The final adoption indexes of sampled adopter households were categorized into three adopter groups namely low, medium and high. The non-adopter group was given a score of 0 and kept as separate category to investigate factors influencing adoption of row planting production package. 
Table 2. Summary of definition of explanatory variables

\begin{tabular}{|c|c|c|c|}
\hline $\begin{array}{l}\text { Variable } \\
\text { code }\end{array}$ & Variable description & Measurement & $\begin{array}{l}\text { Expected } \\
\text { sign }\end{array}$ \\
\hline ADOPTION & $\begin{array}{l}\text { Adoption of teff row planting } \\
\text { technology: farmers who were } \\
\text { using teff row planting at least } \\
\text { for two years and continued } \\
\text { using during } 2016 / 17 \text { crop } \\
\text { season were considered to be } \\
\text { adopters (1) or otherwise non- } \\
\text { adopters }(0) \text {. }\end{array}$ & Dummy & $\begin{array}{l}\text { Dependent } \\
\text { variable }\end{array}$ \\
\hline INTENADO & $\begin{array}{l}\text { Intensity of adoption of the } \\
\text { technology among adopters. } \\
\text { Adoption index indicates } \\
\text { farmers' level of use of } \\
\text { multiple practices from the } \\
\text { recommended teff row planting } \\
\text { technology. }\end{array}$ & Continuous & $\begin{array}{l}\text { Dependent } \\
\text { variable }\end{array}$ \\
\hline 1. SEX & $\begin{array}{l}\text { Sex of the household head } 0= \\
\text { female, } 1=\text { if male }\end{array}$ & Dummy & + \\
\hline 2. EDUCL & $\begin{array}{l}\text { Educational level of the } \\
\text { household head in number of } \\
\text { years of schooling }(1,2,3,4)\end{array}$ & Continuous & + \\
\hline 3. TLU & $\begin{array}{l}\text { Livestock ownership of the } \\
\text { household in TLU }\end{array}$ & Continuous & + \\
\hline 4 FARSIZE & $\begin{array}{l}\text { Farm size in hectare owned by } \\
\text { the household (considering rent } \\
\text { in and rent out) }\end{array}$ & Continuous & + \\
\hline 5. FAREXP & $\begin{array}{l}\text { Farm experience of the } \\
\text { household head (in years) }\end{array}$ & Continuous & + \\
\hline 6. FAMSIZE & $\begin{array}{l}\text { The number of members of } \\
\text { family found in the given } \\
\text { household }\end{array}$ & Continuous & + \\
\hline 7. OFFINC & $\begin{array}{l}\text { Participating in off-farm } \\
\text { activities } 0=\text { no, } 1=\text { if yes }\end{array}$ & Dummy & + \\
\hline 8. FARINC & $\begin{array}{l}\text { Total annual earnings of the } \\
\text { family from sale of agricultural } \\
\text { products (in Ethiopian Birr) }\end{array}$ & Continuous & + \\
\hline 9. COWEXA & $\begin{array}{l}\mathrm{HH} \text { head's contact with } \\
\text { agricultural extension agents on } \\
\text { TRP practice } 0=\text { no, } 1=\text { if yes }\end{array}$ & Dummy & + \\
\hline $\begin{array}{l}10 . \\
\text { FQCOWEXA }\end{array}$ & $\begin{array}{l}\text { The number of contacts with } \\
\text { extension agent per year that } \\
\text { the respondent made with } \\
\text { extension agents. 1) Never 2) } \\
\text { Once in a week 3) twice in a } \\
\text { week 4) monthly 5) yearly }\end{array}$ & Categorical & + \\
\hline
\end{tabular}




\begin{tabular}{|c|c|c|c|}
\hline $\begin{array}{l}11 . \\
\text { ATIIDMO }\end{array}$ & $\begin{array}{l}\text { Participation of respondents in } \\
\text { demonstrations at kebele level } \\
\text { including the FTC } \\
\text { demonstration. } 0 \text { for non- } \\
\text { participants and } 1 \text { for } \\
\text { participants. }\end{array}$ & Dummy & + \\
\hline 12. DISTNM & $\begin{array}{l}\text { Distance to the nearest market } \\
\text { from dwelling areas (in } \mathrm{km} \text { ) }\end{array}$ & Continuous & - \\
\hline $\begin{array}{l}13 . \\
\text { MASMIEX }\end{array}$ & $\begin{array}{l}\text { The exposure of } \mathrm{HH} \text { head mass } \\
\text { media, } 0=\text { no, } 1=\text { if yes }\end{array}$ & Dummy & + \\
\hline 14. ACCTCR & $\begin{array}{l}\mathrm{HH} \text { head's access credit, } 0=\text { no, } \\
1=\text { if yes }\end{array}$ & Dummy & + \\
\hline 15. MEISEM & $\begin{array}{l}\text { Participation of } \mathrm{HH} \text { in seed } \\
\text { multiplication groups, } 0=\text { no, } \\
1=\text { if yes }\end{array}$ & Dummy & + \\
\hline 16. ATFTRP: & $\begin{array}{l}\text { Attitude of respondents } \\
\text { towards teff row planting } \\
\text { technology (measured using } \\
\text { Likert rating scale). }\end{array}$ & Categorical & + \\
\hline
\end{tabular}

This makes up four distinct categories across which adoption and intensity of adoption of row planting production package were assessed. The adoption index score ranges used to classify respondents into non-adopters was 0 , low adopters was 0.01-0.33, medium adopters was $0.34-0.66$ and high adopters was $0.67-1.00$ (Table 3).

Adoption index score ranges from 0 to1. Adoption index score of 0 point implies non-adoption of row planting method but they might be adopting other practices of the production package and adoption index value of 1 implies adoption according to recommendation. For FHH, mean adoption index score of non-adopters was 0.0 , lowadopters was 0.29 , medium adopters was 0.59 and high adopter groups was 0.00 and for $\mathrm{MHH}$ it was 0.0 for non-adopters, 0.29 for low, 0.46 for medium and 0.79 for high-adopters (Table 3). According to the results of the one-way analysis of variance, adoption index scores significantly varied among the four adopter categories $(\mathrm{F}=766.5, \mathrm{P}=000$ for $\mathrm{FHH}$ and $\mathrm{F}=943.9, \mathrm{P}=000$ for $\mathrm{MHH})$. Adoption varied with among sample farmers. 
Table 3. Distribution of respondents by level of adoption

\begin{tabular}{lrrlr}
\hline $\begin{array}{l}\text { Adopter } \\
\text { Category }\end{array}$ & $\mathbf{N}$ & $\mathbf{\%}$ & \multicolumn{2}{c}{$\begin{array}{c}\text { Adoption index } \\
\text { range }\end{array}$} \\
\hline Non-adopters & 57 & 34.8 & 0.0 & \\
Low adopters & 16 & 9.8 & $0.01-0.33$ & \\
Medium adopters & 49 & 29.9 & $0.34-0.66$ & \\
High adopters & 42 & 25.6 & $0.67-1.00$ & \\
Total & 164 & 100.0 & $0-1$ & \\
& & & & All cases \\
& & Mean adoption index & 0.00 \\
Non-adopters & FHH & MHH & 0.48 \\
Low adopters & 0.00 & 0.00 & 0.79 \\
Medium adopters & 0.29 & 0.29 & 0.38 \\
High adopters & 0.59 & 0.46 & $1194.5^{* * *}$ \\
Total & 0.00 & 0.79 & 0.42 & \\
& 0.19 & $943.9^{* * *}$ & & \\
\hline
\end{tabular}

Source: survey data, 2017. *** denotes $1 \%$ level of significance.

Some $80 \%$ of 164 farmers interviewed were male-headed and the rest $20 \%$ female-headed households. The area was generally dominated numerically by male-headed households. Just 107 (65.2\%) of them adopted the technology and $57(34.8 \%)$ did not (Table 4). With respect to gender, majority ( $87.9 \%$ ) of the adopters were male-headed households. Majority (60.6\%) of FHH were non-adopters while about $72 \%$ of $\mathrm{MHH}$ were adopters. There were no high adopters among the FHH adopters. Adoption status and head of the household were significantly associated $(\chi 2$ value $=12.17, \mathrm{P}=0.000)$ (Table 4$)$. That means gender of the household matters in adoption, i.e., women were less adopters than men. Male farmers had access to information, the exposure to participating in attending extension events than the female-headed households. As a result, men had higher probability of becoming adopters than female-headed households. Similar results were reported in previous studies (Behailu, 2014; Fitsum, 2016; Begashaw, 2018). 
Table 4. Adoption status and level of adoption of respondents (\%)

\begin{tabular}{|c|c|c|c|c|c|}
\hline Variables & & $\begin{array}{l}\text { Non- } \\
\text { adopter }\end{array}$ & Adopter & All & $\chi^{2}$ values \\
\hline $\begin{array}{l}\text { Sex of } \\
\text { household }\end{array}$ & $\begin{array}{l}\text { Female } \\
\text { Male } \\
\text { Total }\end{array}$ & $\begin{array}{l}60.6 \\
28.2 \\
34.8\end{array}$ & $\begin{array}{l}39.4 \\
71.8 \\
65.2\end{array}$ & $\begin{array}{r}20.1 \\
79.9 \\
100.0\end{array}$ & $12.2 * * *$ \\
\hline $\begin{array}{l}\text { Adopter } \\
\text { category }\end{array}$ & $\begin{array}{l}\text { None } † \\
\text { Low } \\
\text { Medium } \\
\text { High }\end{array}$ & $\begin{array}{r}\text { FHH } \\
60.6 \\
15.2 \\
24.2 \\
0.0\end{array}$ & $\begin{array}{r}\mathrm{MHH} \\
28.2 \\
8.4 \\
31.3 \\
32.1\end{array}$ & $\begin{array}{r}\text { All } \\
34.8 \\
9.8 \\
29.9 \\
25.6\end{array}$ & $20.2 * * *$ \\
\hline
\end{tabular}

Source: survey data, $2017 ; * * *$ denotes $1 \%$ level of significance, respectively; †"None" stands for non-adopter, Low for low adopter, "Medium" for medium adopter and "High" for high adopter.

\section{Area of teff fields under row planting method}

Sampled farmers owned a total of 267.4 ha land, 84.2 ha (32.5\%) of which was covered with teff crop. From the total land area allocated for teff, only 24.8 ha $(29.5 \%)$ was row-planted. FHH owned about 49 ha $(18 \%)$ of the total 267 ha land. Out of this, 14 ha $(28.1 \%)$ was planted to teff and 2 ha (14.2\%) was row-planted (Table 5).

Table 5. Land holding (ha) of male-headed and female-headed respondents

\begin{tabular}{lrrr}
\hline Area allocation & All cases & FHH & MHH \\
\hline Area allotted for teff & 267.4 & 48.5 & 218.9 \\
Area with row-planted teff & 84.2 & 13.7 & 70.6 \\
Total & 24.8 & 1.9 & 22.9 \\
\hline
\end{tabular}

Source: survey data, 2017

Individual households owned an average of 1.63 ha of farm land, 0.51 (31.5\%) allocated to teff and only 0.23 ha of this $(29.5 \%)$ was rowplanted. On average, FHH farmers row-planted an area of 0.41 ha and MHH 0.54 ha, which were significantly different at $\alpha=0.1$ level of significance $(\mathrm{t}=-1.8, \mathrm{p}=0.078)$. MHH allocated relatively more land for teff than FHH (Table 6). 
Table 6. Mean area coverage of teff production of sample adopter households

\begin{tabular}{lllll}
\hline Variables & $\begin{array}{l}\text { Male } \\
(\mathbf{N}=131)\end{array}$ & $\begin{array}{l}\text { Female } \\
(\mathbf{N}=33)\end{array}$ & $\begin{array}{l}\text { All cases } \\
(\mathbf{N}=164)\end{array}$ & t-value \\
\hline Area of teff (ha) & 0.54 & 0.41 & 0.51 & $-1.80^{*}$ \\
Row planted (ha) & 0.24 & 0.15 & 0.23 & -1.50 \\
Total (ha) & 1.67 & 1.47 & 1.63 & -1.13 \\
\hline
\end{tabular}

Source: survey data, 2017. ${ }^{*}$ denotes $10 \%$ level of significance.

Components of the package included seed rate, fertilizer and spacing. Seed rate recommendations in the study area for row planted teff was $3 \mathrm{~kg} / \mathrm{ha}$ for light and $5 \mathrm{~kg} / \mathrm{ha}$ for black soils. The intra-row spacing of the crop was $20 \mathrm{~cm}$. Fertilizer rate was $50-100 \mathrm{~kg} / \mathrm{ha}$ UREA and 100 $\mathrm{kg} / \mathrm{ha}$ DAP (BOAD Moretna Jiru District, 2016). The mean adoption level of area covered by row Teff sowing of respondents were 0.15 and 0.24 ha for FHH and $\mathrm{MHH}$, respectively (Appendix Table 1).

The average seeding rate was $1.43 \mathrm{~kg}$ for $\mathrm{FHH}$ and $2.55 \mathrm{~kg}$ for sample household. There was significant variation among seed rate adopter categories in terms of their seeding rate. This is evident from results of one-way ANOVA which indicated the presence of significant mean difference in seeding rate applied between $\mathrm{FHH}$ and $\mathrm{MHH}$ adopter categories $(\mathrm{F}=74.98, \mathrm{P}=0.0045$ and $\mathrm{F}=77.63, \mathrm{P}=0.000)$. Access to credit significantly varied between the two groups at $10 \%$ level of significance. Majority (69.7\%) FHH did not use credit while $49 \%$ of MHH used credit services (Table 7 ). Only $23.8 \%$ of the respondents have attended field demonstrations on teff row planting method (Table 7). Only $6.1 \%$ of $\mathrm{FHH}$ and $28.2 \%$ of $\mathrm{MHH}$ participated in demonstrations. Some $57.6 \%$ of FHH and $77.8 \%$ of $\mathrm{MHH}$ respondents had positive attitude towards teff row planting technology related with teff yield increment (Table 7). As to educational status, about $64 \%$ of $\mathrm{FHH}$ and $76 \%$ of $\mathrm{MHH}$ were illiterate. Although all female-headed farmers got extension service on teff row planting method, $30.3 \%$ of this group obtained the service once in a month, whereas $43.5 \%$ of $\mathrm{MHH}$ accessed it at least once in a week. 
Table 7. Summary of chi-square test results of respondents

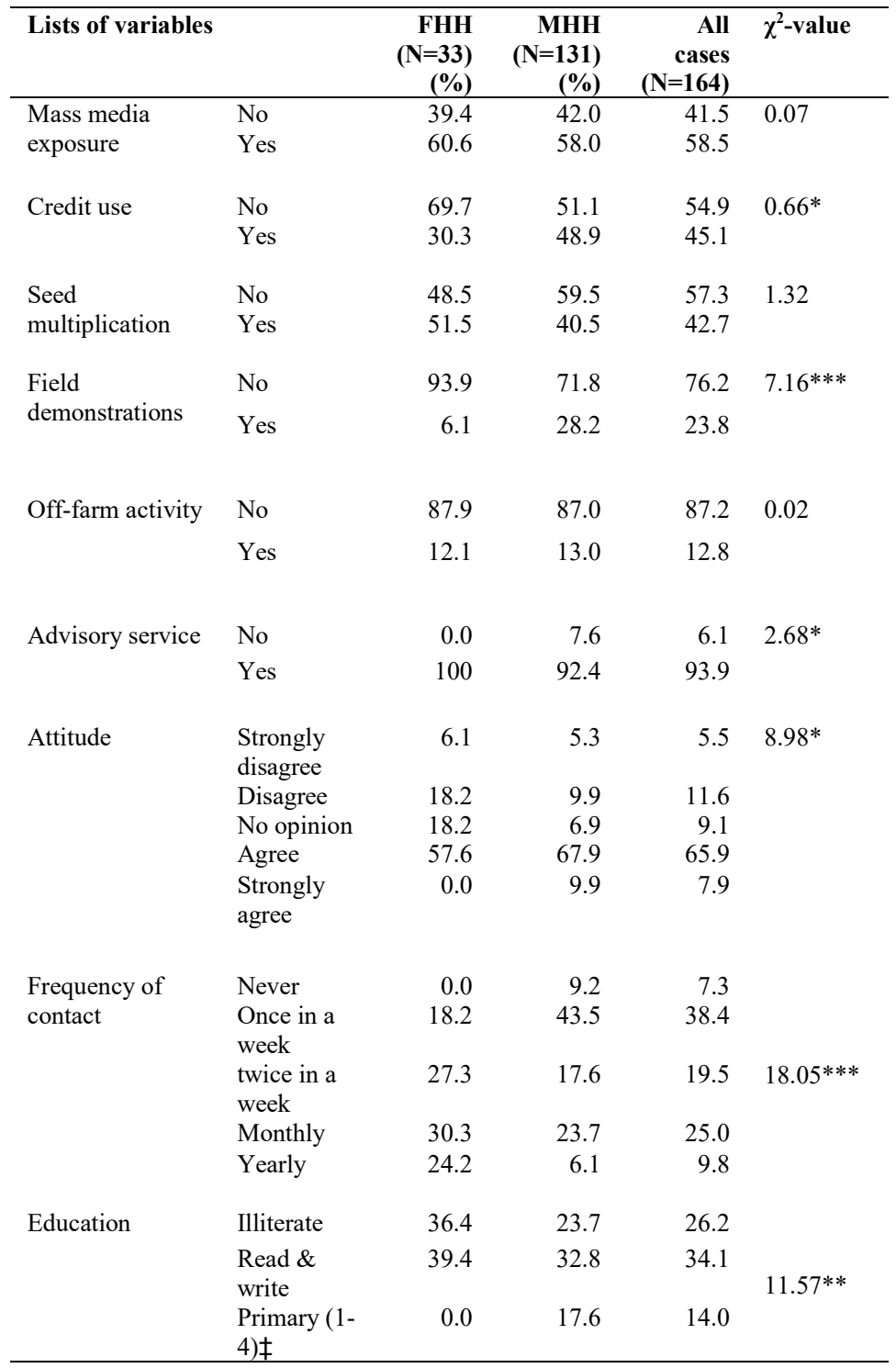




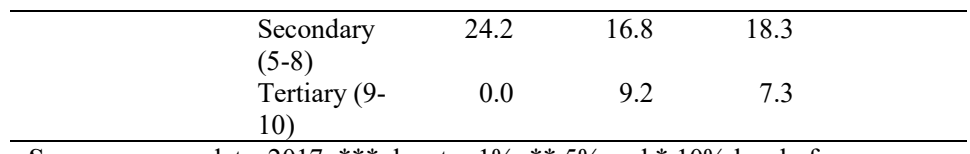

Source: survey data, 2017. *** denotes $1 \%, * * 5 \%$ and $* 10 \%$ level of significance; $¥$ Primary, secondary and tertiary stand for primary, secondary and tertiary cycles.

Regarding the distance taken to travel from home to the nearest market, sample farmers reported that they had to travel an average of $34.8 \mathrm{~km}$. For FHH, average distance that a farmer had to travel to the nearest market was $32.2 \mathrm{~km}$ and MHH $45 \mathrm{~km}$.

Average farm income for sample households was 38,092.32 Birr/year, whereas the mean farm income for FHH was Birr 29,130.30 and that of MHH was 40,349.92 (Table 8). Incomes significantly varied between groups $(\mathrm{t}=2.35, \mathrm{P}=0.025)$.

Table 8. Summary of t-test results of respondents

\begin{tabular}{llrrr}
\hline Variables & \multicolumn{1}{l}{$\begin{array}{l}\text { Male } \\
(\mathbf{N = 1 3 1 )}\end{array}$} & $\begin{array}{l}\text { Female } \\
(\mathbf{N}=\mathbf{3 3})\end{array}$ & \multicolumn{1}{c}{$\begin{array}{l}\text { All cases } \\
(\mathbf{N}=164)\end{array}$} & t-value \\
\hline Experiencef & 22.92 & 21.21 & 22.57 & -0.781 \\
Distance & 32.20 & 45.00 & 34.77 & $2.03^{* *}$ \\
Livestock & 3.48 & 3.06 & 3.40 & -1.26 \\
Farm size, ha & 1.67 & 1.47 & 1.63 & -1.13 \\
Family size & 4.72 & 4.61 & 4.70 & -.321 \\
Income (Birr) & 40,350 & 29,130 & 38,092 & $-2.35^{* *}$ \\
\hline
\end{tabular}

‡Experience stands for farming experience, Distance for Distance to plot in $\mathrm{km}$, Livestock for livestock unit (TLU) owned.

Source: Survey data, 2017; ** denotes $5 \%$ level of significance.

\section{Determinants of adoption and intensity of adoption}

Estimates of the variables expected to contribute for the adoption and intensity of adoption of teff row planting technology package is displayed in Table 9. A total of 16 explanatory variables were included into the econometric model out of which six variables in the pool data, five variables in $\mathrm{MHH}$ and twelve variables in $\mathrm{FHH}$ were found to significantly influence adoption and intensity of teff row planting technology package. For the $\mathrm{FHH}$, four variables were excluded from regression due to lack of variability, i.e., getting extension service, frequency of contact with extension agents, 
attending demonstrations and participating in off-farm income generating activities.

Effect of gender: This variable influenced the adoption decision positively and significantly. The positive sign of the coefficient indicates that male-headed households were more likely to adopt teff row planting technology package than female-headed household heads. The model showed that male gender was found to have $21 \%$ contribution to adoption and intensity of use of teff row planting technology package. The possible explanation might be male headed households have better access to information, agricultural inputs and resource endowments. Similar results were reported before (Techane, 2002; Almaz, 2011; Begashaw, 2018). The econometric result indicates that the educational level of both FHH and MHH household had positive and significant influence on the likelihood of adoption of row planting technology for which educational level accounted for 10 $\%$ and $25 \%$ of the variation in adoption and intensity of adoption of teff row planting of MHH AND FHHH, respectively. The positive association suggests that the likelihood of adopting row planting technology increases as educational level of farmers increases. This finding is in agreement with previous studies (Mulugeta, 2009; Almaz, 2011).

Land holding positively influenced adoption of teff row planting and its intensity. Land holding accounted for about $7 \%$ for $\mathrm{MHH}$ and $15 \%$ for FHH of the variation in adoption and intensity of adoption of teff row planting production package. Contrary to the hypothesis, livestock holding of sample population for both FHH and MHH is negatively and significantly associated with adoption and intensity of teff row planting technology. Consequently, livestock ownership accounted for about $4 \%$ for $\mathrm{MHH}$ and $7 \%$ for $\mathrm{FHH}$ of the variation in the adoption and intensity of adoption. The probable reason might be teff row planting method is labor intensive. Farmer's contact with extension agents was found to be positive and significant to influence on MHH adoption decision of row planting technology (Table 9). The positive association indicates that as farmers' contact with extension agents' increase, the likelihood of adoption increases. This variable accounted for about $24 \%$ of the variation in the adoption and intensity of adoption. 
The result of Tobit model showed that attitude towards teff row planting technology is positively and significantly related with adoption of the package. The above finding implies that those individuals who have unfavorable attitude towards the technology package usually create resistance to accept new ideas and innovations thereby retard the processes of change towards which interventions in rural development are geared. This implies need to change negative attitude held by non-adopters of the technology package. The result from this test in the model shows that attitude towards teff row planting technology package was found to have $23 \%$ for $\mathrm{FHH}$ and $37 \%$ for $\mathrm{MHH}$ contribution to adoption and intensity of use of teff row planting package. The result of this study goes along with previous findings (Ebrahim, 2006; Mekonnen, 2007; Rahmeto, 2007). As expected, in FHH sample respondents, participated in seed multiplication, use of credit, farming experience, and on-farm income had positive influence on adoption and intensity of adoption of row planting package. Participation in seed multiplication accounted for about $23 \%$, use of credit for $16 \%$ and farming experience for $4 \%$ of the variation in adoption and intensity of adoption (Table 9).

Farm distance to home was negatively and significantly associated with the probability of adoption and extent of use of row planting package of teff (Table 9). The negative association indicates that as distance to the plot decreases, the likelihood of adopting the package increases. Distance accounted for about $1 \%$ of the variation in the adoption and intensity of adoption.

In contrast to common knowledge, family size and mass media exposure had negative influence on adoption and intensity of adoption. The negative association means that the likelihood of adopting row planting package declines with increasing family size and exposure to mass media. Further study is required. As indicated in Table 10 below, a higher marginal effect was accounted to sex of the household head and the result showed that being male headed household had influence on the intensity of use of adopting teff row planting technology which increases by $35 \%$, keeping other variables constant. The effect is very immense as compared to the changes resulting from other significant variables implying that priority should be given to improving women participation in adoption of 
agricultural technology in general and Teff row planting technology in particular.

With regard to participated in off farm activity, frequency of extension contact, level of education of the household head, on the average, one birr increase in income, the number of contacts increase with development agents, a unit increase in years of schooling of the household head increases the intensity of use of teff row planting technology by $32 \%, 29 \%$, and $27 \%$, respectively.

In FHH, marginal effect of Tobit model analysis showed that favorable attitude towards the technology increases the intensity of use of teff row planting technology by $81 \%$, a year increase in schooling by $39 \%$ and one ha increase in land holding by $30 \%$.

In $\mathrm{MHH}$, favorable/positive attitude towards the technology increases the intensity of use of the technology by $39 \%$, getting extension service by $38 \%$ and a level increase in education by $24 \%$.

\section{CONCLUSION}

Teff row planting technology is among the newly introduced technologies aimed to increase Teff productivity in Ethiopia. However, the adoption of this technology is constrained by different factors such as economic, institutional, demographic, household specific and other factors. The process of developing and implementing Teff row planting technology needs close work, collaboration, and consultation with the main concerned bodies: Research centers, Universities, Agricultural extension office and mainly with farmers. This intern helps to ensure identifying needs, problems and prioritizing problems in order to get viable solutions. 
Table 9. Determinants of adoption and intensity of adoption

\begin{tabular}{|c|c|c|c|c|c|c|}
\hline \multirow{2}{*}{$\begin{array}{l}\text { Explanatory } \\
\text { variable }\end{array}$} & \multicolumn{2}{|c|}{ Pooled $(\mathrm{N}=164)$} & \multicolumn{2}{|c|}{ MHH (N=131) } & \multicolumn{2}{|c|}{ FHH $(\mathbf{N}=33)$} \\
\hline & Coefficient & Marginal effect & Coefficient & Marginal effect & Coefficient & Marginal effect \\
\hline SEX & $0.21(0.07)^{* * *}$ & 0.21 & $\begin{array}{ll}----- \\
\end{array}$ & ----- & $\begin{array}{ll}----- \\
\end{array}$ & $\begin{array}{ll}---- \\
\end{array}$ \\
\hline EDUCA & $0.12(0.02)^{* * *}$ & 0.12 & $0.10(0.03)^{* * *}$ & 0.10 & $0.25\left(6.4 \mathrm{E}^{-11}\right)^{* * *}$ & 0.25 \\
\hline EXPE & $0.00(0.00)$ & 0.00 & $0.00(0.00)$ & 0.00 & $0.04\left(8.6 \mathrm{E}^{-12}\right) * * *$ & 0.04 \\
\hline DISDC & $0.00(0.00)$ & -0.00 & $0.00(0.00)$ & 0.00 & $-0.01\left(2.9 \mathrm{E}^{-12}\right) * * *$ & -0.01 \\
\hline TLU & $-0.02(0.02)$ & -0.02 & $-0.04(0.02)^{* *}$ & -0.04 & $-0.07\left(4.3 \mathrm{E}^{-11}\right) * * *$ & -0.07 \\
\hline LANDH & $0.04(0.03)$ & 0.04 & $0.07(0.04)^{*}$ & 0.07 & $0.15\left(1.6 \mathrm{E}^{-10}\right) * * *$ & 0.15 \\
\hline FAMS & $0.02(0.02)$ & 0.02 & $0.02(0.02)$ & 0.02 & $-0.14\left(5.3 \mathrm{E}^{-11}\right) * * *$ & -0.14 \\
\hline INCOM & $0.00(0.00)$ & -0.00 & $0.00(0.00)$ & 0.00 & $0.00\left(6.9 \mathrm{E}^{-15}\right) * * *$ & 0.00 \\
\hline EXTEN & $0.26(0.11)^{* *}$ & 0.26 & $0.24(0.11)^{* *}$ & 0.24 & ----- & ------- \\
\hline FEXTEN & $-0.05(0.03) *$ & -0.05 & $-0.03(0.03)$ & -0.03 & ------ & ------- \\
\hline DEMON & $-0.03(0.06)$ & -0.03 & $-0.01(0.06)$ & -0.01 & ------ & ------- \\
\hline OFFIN & $0.14(0.07)^{* *}$ & 0.14 & $0.11(0.08)$ & 0.11 & ------ & ------ \\
\hline ATTIUD & $0.37(0.05)^{* * *}$ & 0.37 & $0.37(0.05)^{* * *}$ & 0.37 & $0.23\left(5.8 \mathrm{E}^{-11}\right) * * *$ & 0.23 \\
\hline SEED & $0.08(0.06)$ & 0.08 & $0.06(0.07)$ & 0.06 & $0.23\left(2.1 \mathrm{E}-{ }^{10}\right) * * *$ & 0.23 \\
\hline MASS & $0.05(0.07)$ & 0.05 & $0.07(0.07)$ & 0.07 & $-0.22\left(2.0 \mathrm{E}^{-10}\right) * * *$ & -0.22 \\
\hline CREDIT & $0.03(0.05)$ & 0.29 & $0.03(0.06)$ & 0.03 & $0.16\left(1.3 \mathrm{E}^{-10}\right) * * *$ & 0.16 \\
\hline CONSTANT & $-1.83(0.23)^{* * *}$ & - & $-1.55(0.22)^{* * *}$ & - & $-1.33\left(2.4 \mathrm{E}^{-10}\right) * * *$ & ----- \\
\hline \multicolumn{3}{|c|}{$\operatorname{LR} \chi^{2}(16)=189.82 * * *$} & \multicolumn{2}{|c|}{$\operatorname{LR} \chi^{2}(16)=135.99^{* * *}$} & \multicolumn{2}{|c|}{$\operatorname{LR} \chi^{2}(16)=76.80^{* * *}$} \\
\hline \multicolumn{3}{|c|}{ Log likelihood $=-31.61$} & \multicolumn{2}{|c|}{ Log likelihood $=-27.06$} & \multicolumn{2}{|c|}{ Log likelihood $=226.22$} \\
\hline \multicolumn{3}{|c|}{ Pseudo $\mathrm{R}^{2}=0.75$} & \multicolumn{2}{|c|}{ Pseudo $\mathrm{R}^{2}=0.72$} & \multicolumn{2}{|c|}{ Pseudo $\mathrm{R}^{2}=10.37$} \\
\hline
\end{tabular}

Source: survey data, 2017.*** denotes $1 \%, * * 5 \%$ and $* 10 \%$ level of significance. 
Table 10. Marginal effects of determinant variables

\begin{tabular}{|c|c|c|c|c|c|}
\hline \multirow[t]{2}{*}{$\begin{array}{l}\text { Variables pooled } \\
(\mathrm{N}=164)\end{array}$} & \multirow[t]{2}{*}{$\begin{array}{c}\text { Change in the intensity of } \\
\text { adoption* } \\
\text { (Pooled }(\mathbf{N}=164) \\
\partial E\left(Y \mid Y_{i}^{*}>0\right)\end{array}$} & \multirow[t]{2}{*}{$\begin{array}{l}\text { Variables } \\
\text { MHH } \\
(\mathrm{N}=131)\end{array}$} & $\begin{array}{c}\text { Change in the } \\
\text { intensity of adoption* } \\
\text { MHH } \\
\partial E\left(Y \mid Y_{i}^{*}>0\right)\end{array}$ & \multirow[t]{2}{*}{$\begin{array}{l}\text { Variables } \\
\text { FHH } \\
(\mathrm{N}=33)\end{array}$} & \multirow{2}{*}{$\begin{array}{l}\text { Change in the intensity of } \\
\text { adoption* FHH } \\
\frac{\partial E\left(Y \mid Y_{i}^{*}>0\right)}{\partial X_{i}}\end{array}$} \\
\hline & & & $\partial E\left(Y \mid Y_{i}^{*}>0\right)$ & & \\
\hline SEX & 0.35 & EDUCA & 0.24 & EDUCA & 0.39 \\
\hline ATTIUD & 0.11 & TLU & -0.05 & EXPE & 0.03 \\
\hline EDUCA & 0.27 & LAND & 0.08 & DISDC & 0.00 \\
\hline EXTEN & -0.04 & EXTEN & 0.38 & TLU & -0.06 \\
\hline FEXTEN & 0.29 & ATTIUD & 0.39 & LANDH & 0.30 \\
\hline \multirow[t]{6}{*}{ OFFINCO } & 0.32 & & & FAMS & -0.19 \\
\hline & & & & INCOM & 0.01 \\
\hline & & & & ATTIUD & 0.81 \\
\hline & & & & SEED & 0.25 \\
\hline & & & & MASS & -0.21 \\
\hline & & & & CREDIT & 0.16 \\
\hline
\end{tabular}

Source: survey data, 2017. 
Majority of FHH respondents were non-adopters. Besides the mean teff row planting technology by $\mathrm{FHH}$ is below the recommendation. Hence, attention should be given for female household by empowering them to participate in Teff row planting technology.

Extension agents should work hard with female-headed farmers and to ensure the implementation of Teff row planting technology based on recommendation there by strengthen FTCs in well-coordinated manner by fulfilling the necessary materials to increase adoption rate of the technology. The government extension workers should focus to facilitate and organize field days of Teff row planting method at different stage of agronomic practice near the farmers' locality. This practical lesson can initiate and convince the non-adopters to apply the technology based on its recommendation.

\section{ACKNOWLEDGMENTS}

We would like to thank those who helped us to collect the data and all respondents who devoted their time in replying for the interview schedule.

\section{REFERENCES}

Almaz, G. (2011). Adoption of improved chickpea technology packages in East Shewa, Ethiopia Journal of Agricultural Extension Management 12(1): 20-3

ATA (Agricultural Transformation Agency). (2013a). Results of 2012 New Tef Technologies Demonstration Trials Draft Report VF. Addis Ababa, Ethiopia.

ATA (Agricultural Transformation Agency). (2013b). Working Strategy for Strengthening Ethiopian's Tef Value Chain Vision, Systemic Challenges, and Prioritized Interventions. Addis Ababa, Ethiopia

ATA (Agricultural Transformation Agency). (2016). Transforming Agriculture in Ethiopia. Annual report 2015/2016. [accessed online on 26/10/2016].

Abebe, B and Workayehu, T. (2015). Effect of method of sowing and time of di-ammonium phosphate (dap) fertilizer application, on yield and yield components of tef (Eragrostis tef) Trotter) at Shebedino, Southern 
Ethiopia. Advanced Crop Science Technology 3: 168. doi:10.4172/23298863.1000168

Begashaw, M. (2018). Determinants of adoption of teff (Eragrostis tef) row planting technology in Moretna Jiru Woreda, North Shoa Zone of Amhara Regional State, Ethiopia. MSc thesis Bahir Dar University, Ethiopia. 122pp

Behailu, G. (2014). Assessment of factors affecting farmers' adoption level of row planting technology and yield improvement on the production of Eragrostis tef [Zucc.]: The case of Minjar Shenkora Woreda, Amhara Region, Ethiopia. Addis Ababa University.

Berhe, T and Zena, N. (2008). Results in a trial of system of teff intensification (STI) at Debre Zeit, Ethiopia.

Berhe, T. (2009). Recent Developments in tef, Ethiopia's most important cereal and gift of the world. CIIFAD Forum Seminar, Addis Ababa, Ethiopia.

BOAD (Bureau of Agriculture and Rural Development). (2016). Annual report, North Shoa, Moretna Jiru district.

Debelo, D. (2015). Does adoption of quncho tef increases farmers' crops income? Evidence from small holder farmers in Wayu Tuqa District, Oromia Regional State, Ethiopia. Journal of Economics and Sustainable Development 6(17): 87-102

Ebrahim, J. (2006). Adoption of diary innovation: Its income and gender implication in Adami Tulu District, Ethiopia. An M.Sc. Thesis Haramaya University, Ethiopia.

Fistum, M. (2016). Analysis of factors affecting adoption of soya bean production technology in Pawe District, Metekel Zone of Benishangul Gumz Regional State, Ethiopia. World Scientific News 53(3): 122-137

Fufa, B., Behute, B. Simons, R and Berhe, T. (2011). Tef diagnostic report: strengthening the tef value chain in Ethiopia. Addis Ababa, Ethiopia. Pages: 1560-1599.

Geremew, K. Abdi Bedilu, M. and Workineh, M. (2016). Analysis of smallholder farmer's adoption and continued application of teff row planting technique in Wolaita Zone, Southern Ethiopia. International Journal of Advanced R 7(3): 1370-1375.

MoFED (Ministry of Finance and Economic Development), 2010. Federal democratic republic of Ethiopia: Global agricultural and food security program, Addis Ababa.

Moretena Jiru Woreda Office of Agriculture. (2014). Annual Agriculture Report. Enewari, Ethiopia. Unpublished.

Moretena Jiru Woreda office of Agriculture. (2016). Annual Agriculture Report. Enewari, Ethiopia. Unpublished.

Mekonnen, S. (2007). Assessment of factors influencing adoption of integrated striga management technologies of sorghum in Habro and 
Fedis Woredas, Oromia region. An M.Sc. Thesis, Haramaya University, Ethiopia.

Mulugeta, A. (2009). Determinants of intensity of adoption of old coffee stumping technology in Dale Woreda, SNNPS, Ethiopia. M.SC. Thesis, Haramaya University.

Rahmeto, N. (2007). Determinants of adoption of improved haricot bean production package in Alaba Special Woreda, Southern Ethiopia. An M. Sc Thesis, Haramaya University, Ethiopia.

Rogers, E and Shoe Maker, F. (1983). Communication of innovation: A cross cultural approach. 3rd. Ed. New York: The Free Press.

Singh, S.N. (1992). Achievement motivation scale: In UDAI PAREEK and T.V., RAO. Handbook of Psychological and Social Instruments. Ahmedabad, Indian Institute of Management.

Techane, A. (2002). Determinants of fertilizer adoption in Ethiopia: The case of major cereal producing areas. An M. Sc Thesis Submitted to the School of Graduate Studies of Haramaya University, Ethiopia.130pp

Vandercasteelen, J., Mekdim, D., Bart, M. and Alemayehu, S. (2016). Row planting teff in Ethiopia: Impact on farm-level profitability and labor allocation. Summary of ESSP Working Paper 92.

Yonas, B. (2014). The Impact of row planting of teff crop on rural household income: A case of Tahtay Maychew district, Tigray, Ethiopia. M.Sc. Thesis, Mekele University, Ethiopia. 


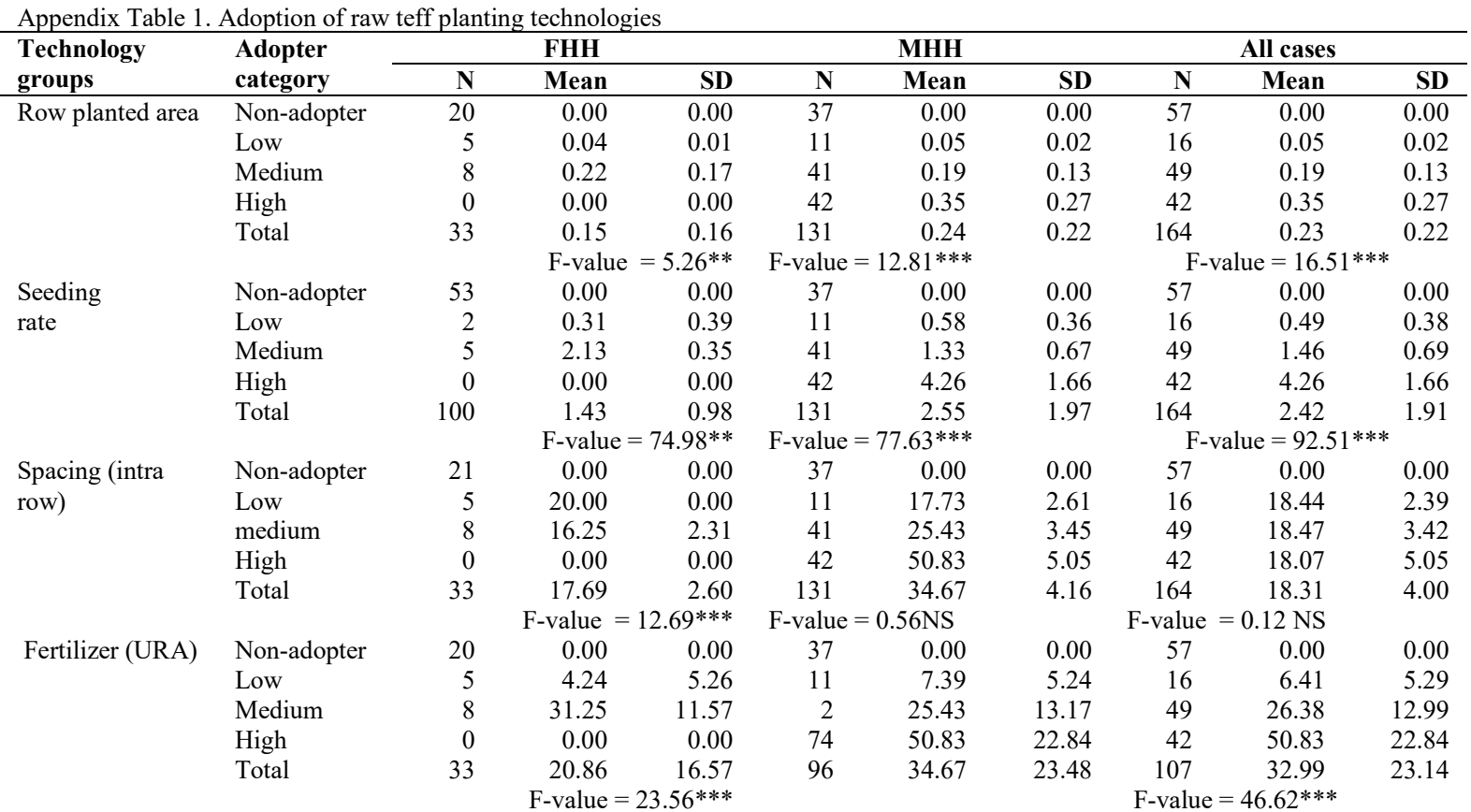




\begin{tabular}{|c|c|c|c|c|c|c|c|c|c|c|}
\hline \multirow[t]{6}{*}{ Fertilizer (DAP) } & Non -adopter & 20 & 0.00 & 0.00 & 37 & 0 & 0.00 & 57 & 0.00 & 0.00 \\
\hline & Low & 5 & 4.48 & 5.04 & 11 & 11 & 9.66 & 16 & 8.04 & 6.92 \\
\hline & Medium & 8 & 43.75 & 11.57 & 41 & 41 & 28.41 & 49 & 30.92 & 14.87 \\
\hline & High & 0 & 0.00 & 0.00 & 42 & 42 & 60.68 & 42 & 60.68 & 34.18 \\
\hline & Total & 33 & 28.65 & 21.95 & 131 & 94 & 40.64 & 164 & 39.18 & 30.33 \\
\hline & & & \multicolumn{2}{|c|}{$\mathrm{F}$-value $=50.23 * * *$} & \multicolumn{3}{|c|}{$\mathrm{F}$-value $=27.01 * * *$} & \multicolumn{3}{|c|}{ F-value $=3.61 * * *$} \\
\hline Weeding & Non-adopter & 22 & 0.00 & 0.20 & 69 & 0.00 & 0.00 & 91 & 0.00 & 0.00 \\
\hline \multirow[t]{5}{*}{ Frequency } & Low & 5 & 2.40 & 0.89 & 11 & 2.00 & 0.77 & 16 & 2.13 & 0.81 \\
\hline & Medium & 6 & 1.33 & 0.52 & 34 & 1.85 & 0.70 & 40 & 1.78 & 0.70 \\
\hline & High & 0 & 0.00 & 0.00 & 17 & 1.65 & 0.70 & 17 & 1.65 & 0.70 \\
\hline & Total & 33 & 1.82 & 0.87 & 131 & 1.82 & 0.71 & 131 & 1.82 & 0.73 \\
\hline & & & \multicolumn{2}{|c|}{$\mathrm{F}$-value $=50.23 * * *$} & \multicolumn{3}{|c|}{ F-value $=0.9 \mathrm{NS}$} & \multicolumn{3}{|c|}{$\mathrm{F}$-value $=2.00 \mathrm{NS}$} \\
\hline Teff row & Non-adopter & 20 & 0.00 & 0.00 & 37 & 0.00 & 0.00 & 57 & 0.00 & 0.00 \\
\hline planting & Low & 5 & 0.31 & 0.39 & 11 & 0.29 & 0.03 & 16 & 0.29 & 0.03 \\
\hline technology & Medium & 8 & 2.13 & 0.35 & 41 & 0.46 & 0.08 & 49 & 0.48 & 0.09 \\
\hline \multirow[t]{3}{*}{ package } & High & 0 & 0.00 & 0.00 & 42 & 0.79 & 0.08 & 42 & 0.79 & 0.08 \\
\hline & \multirow[t]{2}{*}{ Total } & 33 & 1.43 & 0.98 & 131 & 0.42 & 0.32 & 164 & 0.38 & 0.32 \\
\hline & & & \multicolumn{2}{|c|}{$\mathrm{F}$-value $=766.46^{* * *}$} & \multicolumn{3}{|c|}{$\mathrm{F}$-value $=943.93^{* * *}$} & \multicolumn{3}{|c|}{$\mathrm{F}$-value $=1194.54 * * *$} \\
\hline
\end{tabular}

Source: Own survey data, 20017; ***= the mean difference is significant at less $1 \%$ level 